2020 Global Marketing Conference at Seoul Proceedings: 465-467 (November 2020) https://doi.org/10.15444/GMC2020.04.06.03

\title{
HOW INFLUENCERS AND DIGITAL INTERACTION CAN IMPACT CUSTOMER-BRAND RELATIONSHIP AND ENGAGEMENT
}

\author{
Ricardo Godinho Bilro, Instituto Universitário de Lisboa (ISCTE-IUL), Business \\ Research Unit(BRU-IUL), Portugal ${ }^{1}$ \\ Sandra Maria Correia Loureiro, Instituto Universitário de Lisboa (ISCTE-IUL), \\ Business Research Unit (BRU-IUL), Portugal ${ }^{2}$ \\ João Guerreiro, Instituto Universitário de Lisboa (ISCTE-IUL), Business Research \\ Unit (BRU-IUL), Portugal ${ }^{3}$ \\ David Raposo, Instituto Universitário de Lisboa (ISCTE-IUL), Portugal
}

\begin{abstract}
Introduction

This research seeks to unveil how YouTube influencers and digital interaction can contribute to the process of customer-brand relationship and engagement. Based on in-depth interviews of female Youtubers devoted to the lifestyle categories, we aim to comprehend the engagement factors that influencers should rely on to promote engagement between their followers and the brands they advocate.
\end{abstract}

\section{Theoretical Development}

The emergence of social media has changed the ways customers communicate and bond with one another and with brands (Kupfer et al., 2018). People forward news to their friends, or YouTube videos to their relatives, send restaurant reviews to their neighbours, and share stories, news, and information with peers (Bilro et al., 2018; Lamberton \& Stephen, 2016; Mulvey et al., 2019). Moreover, the emergence of social media such as Facebook, Twitter or YouTube, has boosted interest in the word of mouth and viral marketing, which are considered ways of promotion or communication, leading to the arising of social media marketing (Buckley et al., 2012). By applying social media in the marketing efforts, one can use social media technologies, channels and a set of software to create, communicate, deliver, and exchange content with value for organisations and its stakeholders (Tuten \& MintuWimsatt, 2018).

\section{Research Design}

Exploratory research is performed through in-depth interviews with these digital content creators. In-depth interviews are unique in a way they allow to explore the subjects on a one-to-one basis, fostering the interaction between the interviewer and the respondent (Sarstedt \& Mooi, 2014), and enable to collect qualitative data (Raskind et al., 2019). The methodological process started with a comprehensive research process based on existing literature that could lead us to create the appropriate questions to use in the in-depth interview process.

\section{Results and conclusion}

\footnotetext{
${ }^{1}$ bilro.ricardo@gmail.com

2 sandramloureiro@netcabo.pt

3 joao.guerreiro@iscte-iul.pt
} 
Our results put in evidence what are the YouTubers profiles that better lead to brand engagement. When a customer is already identified with the brand and its features, the engagement process becomes more natural, and hence it finds to be more active. Our results also show that two of the Influencers are not associated with any engagement factor, while the other two are related to five or more engagement factors. In this study, researchers consider that YouTubers that better engage with their followers are those who are associated with three or more engagement factors.

This research also put in evidence some characteristics that lead YouTubers to help enhance engagement. Based on this research, we may claim that YouTubers are connected with their followers and associated with authenticity, credibility, and visually appealing content. Concerning credibility, which is determined by trustworthiness and expertise (Xiao and colleagues, 2018), is one of the engagement factors that are related to a higher number of YouTubers. This research also supports what Xiao and colleagues (2018) said, as they have mentioned that credibility and connectedness with followers are two characteristics that are related to each other. Authenticity was also referred to as a typical influencer's trait (Syrdal \& Briggs, 2018) and the current paper witnessed that such engagement factor is the second most related to the YouTubers interviewed.

Keywords: Influencer marketing, YouTubers, Customer-brand relationship, Customer Engagement

\section{References}

Bilro, R. G., Loureiro, S. M. C., \& Ali, F. (2018). The role of website stimuli of experience on engagement and brand advocacy. Journal of Hospitality and Tourism Technology, 9(2), 204-222. https://doi.org/10.1108/JHTT-12-20170136

Buckley, M., Chen, J., Durkheimer, M., Krohnstad, H., Liu, H., Mcdevitt, L., Pirani, A., Pollack, J., Wang, R., Bazerman, M., Beshears, J., Haidt, J., Heath, C., Kashima, Y., Keltner, D., Peters, K., Schaller, M., Small, D., Stephen, A., ... Milkman, K. L. (2012). What Makes Online Content Viral? Journal of Marketing Research, XLIX(April), 192-205. https://doi.org/10.1108/sd.2012.05628haa.014

Kupfer, A.-K., Pähler vor der Holte, N., Kübler, R. V, \& Hennig-Thurau, T. (2018). The Role of the Partner Brand's Social Media Power in Brand Alliances. Journal of Marketing, 82(3), 25-44. https://doi.org/10.1509/jm.15.0536

Lamberton, C., \& Stephen, A. T. (2016). A Thematic Exploration of Digital, Social Media, and Mobile Marketing Research's Evolution from 2000 to 2015 and an Agenda for Future Research. Journal of Marketing, 80(6), 146-172. https://doi.org/10.1509/jm.15.0415

Mulvey, M. S., Lever, M. W., \& Elliot, S. (2019). A Cross-National Comparison of Intra-Generational Variability in Social Media Sharing. Journal of Travel Research, In press, 1-17. https://doi.org/10.1177/0047287519878511

Raskind, I. G., Shelton, R. C., Comeau, D. L., Cooper, H. L. F., Griffith, D. M., \& Kegler, M. C. (2019). A Review of Qualitative Data Analysis Practices in Health Education and Health Behavior Research. Health Education and Behavior, 46(1), 32-39. https://doi.org/10.1177/1090198118795019

Sarstedt, M., \& Mooi, E. (2014). A Concise Guide to Market Research (Second Edi). Springer. https://doi.org/10.1007/978-3-642-53965-7 
Tuten, T., \& Mintu-Wimsatt, A. (2018). Advancing Our Understanding of the Theory and Practice of Social Media Marketing: Introduction To the Special Issue. Journal of Marketing Theory and Practice, 26(1-2), 1-3.

https://doi.org/10.1080/10696679.2018.1393277 